\title{
Relationship between Mechanical Properties in 42SiCr and 42SiMn Medium-car- bon Steels and Austempering Temperatures
}

\author{
Štěpán Jeníček, Michal Peković, Kateřina Opatová, Ivan Vorel \\ University of West Bohemia, Regional Technological Institute, Univerzitní 22, Plzeň, Czech Republic \\ E-mail: opatovak@rti.zcu.cz
}

In conventional steels, bainitic microstructure which forms under isothermal conditions consists of bainitic ferrite and carbide precipitates whose distribution and size substantially depend on the parameters of isothermal treatment. In CFB steels (Carbide Free Bainite) however, the main microstructural constituents are bainitic ferrite, retained austenite and, sometimes, the M-A constituent. CFB microstructure may possess better ductility and the same or even higher strength than microstructures of bainitic ferrite and carbide precipitates. This advantage results from the principle of formation of the CFB microstructure and is related to the absence of brittle carbides and their substitution with retained austenite. This paper explores the effect of austempering on mechanical properties of unconventional CFB steels 42SiCr and 42SiMn.

Keywords: Austempering, CFB structure, Silicon, Mechanical properties

\section{Introduction}

CFB (Carbide Free Bainite) steels are new-generation steels which possess an attractive combination of mechanical properties for technical applications [1]. These properties are dictated by their structure which ideally comprises carbide-free bainitic ferrite and retained austenite. Isothermal treatment in the bainitic transformation region can only produce CFB structure if the steel contains a sufficient amount of silicon or aluminium $[2,3]$. When the formation of carbide precipitates during isothermal treatment is suppressed, bainitic transformation remains incomplete. It is a consequence of thermodynamic processes related to the migration of carbon between the newlyformed ferrite and still-untransformed austenite in its vicinity $[4,5]$. Since carbon has a different solubility in each of the phases, isothermal annealing of CFB steels causes untransformed austenite to become enriched with carbon. With more carbon, untransformed austenite becomes more stable. In other words, the temperature at which bainitic ferrite forms becomes lower. If the amount of carbon in untransformed austenite reaches a critical level during isothermal treatment, the temperature of bainitic transformation drops to or below the current temperature of the material [6]. This substantially hinders the austenite-bainite transformation which can only continue to a very limited extent [7]. The resulting properties depend on the structure of the CFB steel which is, in turn, dictated by its chemical composition and the isothermal treatment temperature.

\section{Materials and methods}

The materials were medium-carbon low-alloy steels $42 \mathrm{SiCr}(0.42 \% \mathrm{C}, 0.62 \% \mathrm{Mn}, 2 \% \mathrm{Si}, 1.33 \% \mathrm{Cr})$ and $42 \mathrm{SiMn}(0.42 \% \mathrm{C}, 0.62 \% \mathrm{Mn}, 2 \% \mathrm{Si}, 0.03 \% \mathrm{Cr})$. They were supplied in the form of $60-\mathrm{kg}$ ingots. They were sectioned and homogenized for 6 hours at $1200^{\circ} \mathrm{C}$ in an argon atmosphere and normalized at $950^{\circ} \mathrm{C}$ for 2 hours. The annealed material was hot-forged into bars $18 \mathrm{~mm}$ in diameter. The forged bars were homogenized at $1200^{\circ} \mathrm{C}$ for 3 hours in a protective atmosphere and normalized at $950^{\circ} \mathrm{C}$ for 2 hours. Specimens for processing in a thermomechanical simulator were machined from the bars. TTT and austenitization diagrams for the steels were determined using JMatPro software, as well as approximate temperatures and times for full austenitizing and homogenization, temperature windows for isothermal decomposition of austenite into bainite and approximate Ms temperatures (Fig. 1). Isothermal treatment routes were proposed for exploring the effect of isothermal treatment temperature on mechanical properties in these steels (Fig. 2). Each of the routes was repeated three times. Test pieces for tensile testing and microstructure observation were then prepared from the processed specimens.

The instruments used for microstructure observation included scanning electron microscopes TESCAN VEGA SB Easy Probe, and SEM-FIB Cross Beam Auriga. The etchant was 3\% nital. Heat treatment and tensile testing was carried out in thermomechanical simulator MTS 810 with induction-resistive heating devices and testing grips, respectively [8]. 

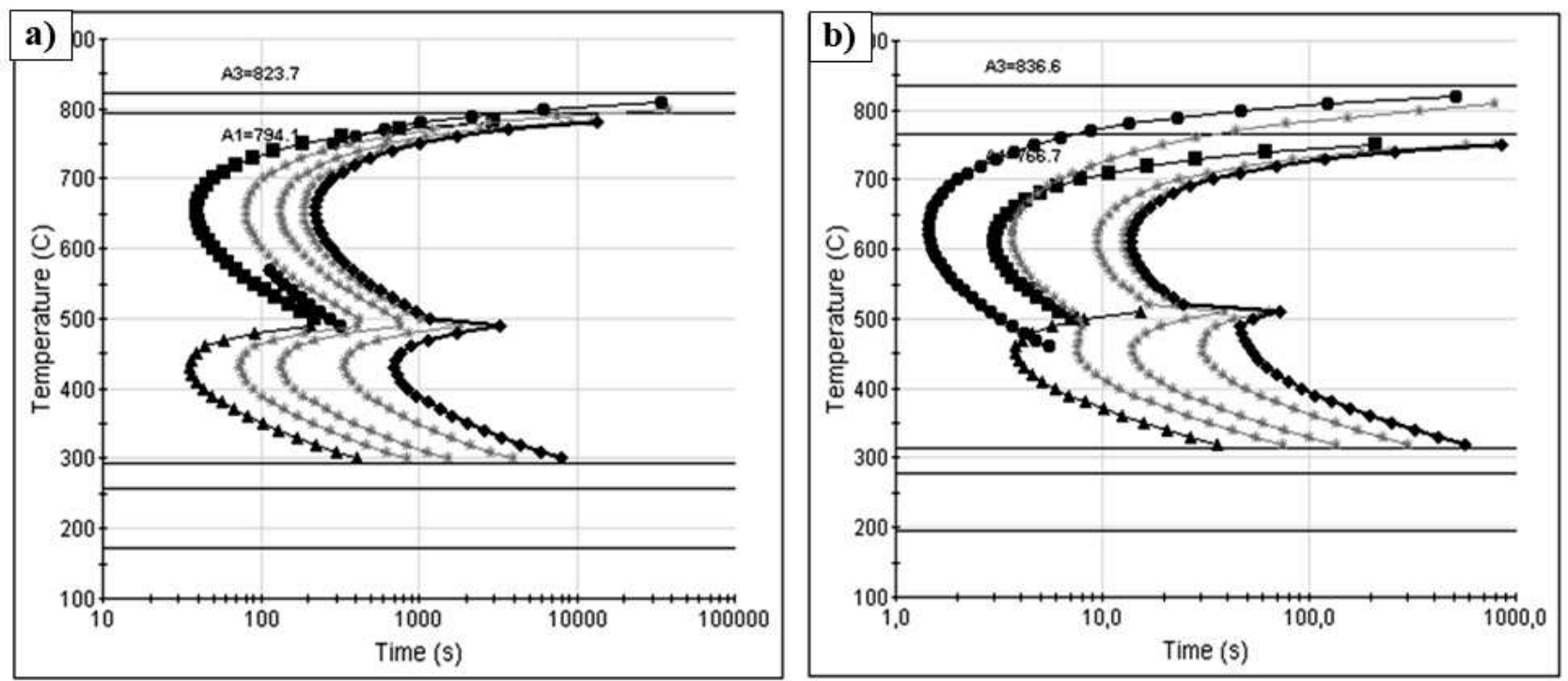

Fig. 1 TTT diagrams of the steels a) 42SiCr b) $42 \mathrm{SiMn}$

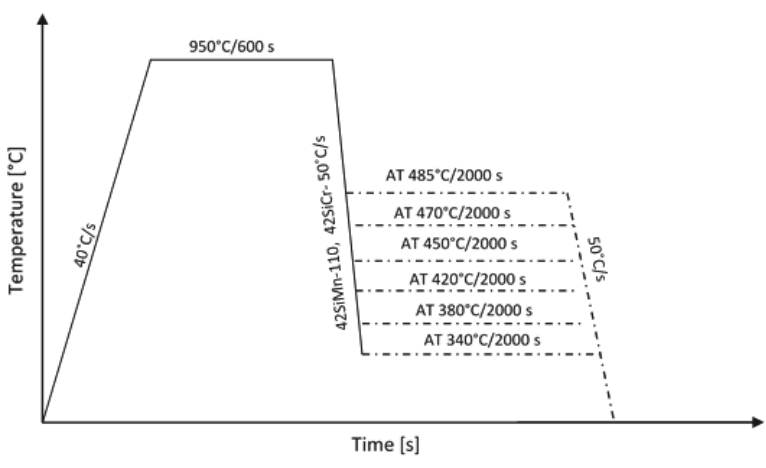

Fig. 2 Diagram of heat treatment routes

\section{Results and discussion}

Ultimate tensile strength (UTS) data led to important conclusions (Fig. 3, Tab. 1). Among the specimens of 42SiMn steel, the ones with the lowest average strength (UTS $=907 \pm 16 \mathrm{MPa}$ ) were those treated according to AT $485^{\circ} \mathrm{C} / 2000 \mathrm{~s}$. The highest strength, in turn, was UTS $=1313 \pm 18 \mathrm{MPa}$ for AT $340^{\circ} \mathrm{C} / 2000$ s specimens. In all specimens of $42 \mathrm{SiMn}$, the microstructure consisted of a majority of bainitic ferrite, carbide precipitates and possibly unstable retained austenite and a small amount of martensite (Fig. 4). With the isothermal treatment temperatures lowered in each subsequent route, the microstructures became finer which was consistent with increasing strength of the specimens. In $42 \mathrm{SiCr}$, the trend in UTS was different. In $42 \mathrm{SiCr}$, the highest average strength UTS $=2073 \pm 36 \mathrm{MPa}$ was obtained with the AT $485^{\circ} \mathrm{C} / 2000$ s route. Interestingly, the same route led to the lowest strength in the other steel, 42SiMn. The cause of this difference in UTS in 42SiCr was the presence of a large fraction of virgin martensite due to incomplete bainitic transformation. As the isothermal treatment temperature was lowered, the amount of virgin martensite decreased, leading to lower strengths, down to UTS $=1363 \pm 18 \mathrm{MPa}$ for the AT $380^{\circ} \mathrm{C} / 2000$ s route. The eventual increase to UTS $=$ $1542 \pm 14 \mathrm{MPa}$ for the AT $340^{\circ} \mathrm{C} / 2000$ s route was most likely due to the overall refinement of the bainitic structure.

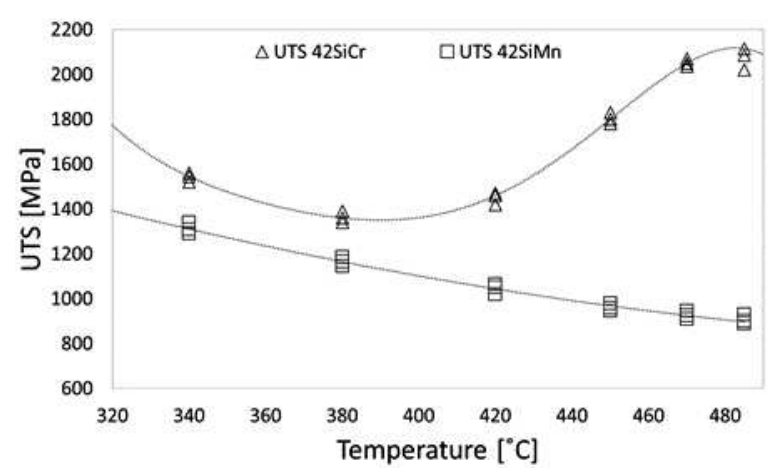

Fig. 3 Ultimate tensile strength (UTS) in austempered (AT) specimens of $42 \mathrm{SiCr}$ and $42 \mathrm{SiMn}$ after isothermal treatment

Tab. 1 Ultimate tensile strength (UTS) in austempered specimens of 42SiCr and 42SiMn after isothermal treatment

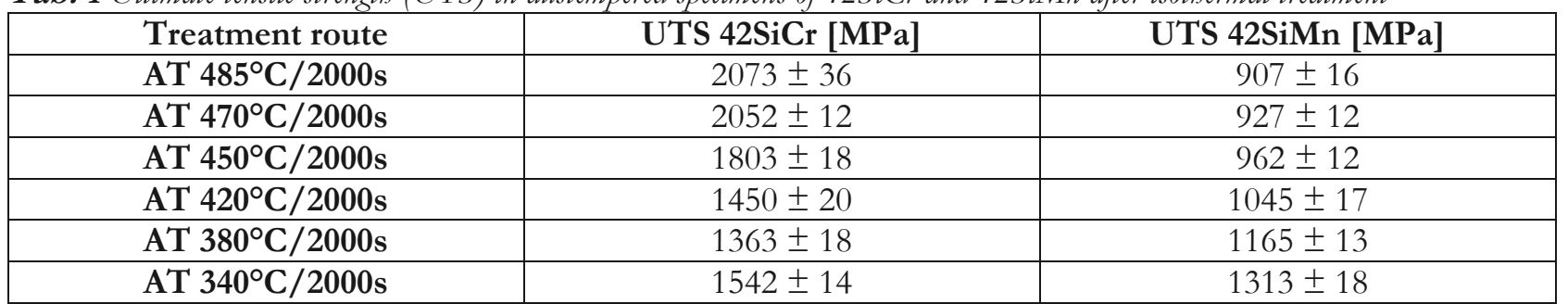



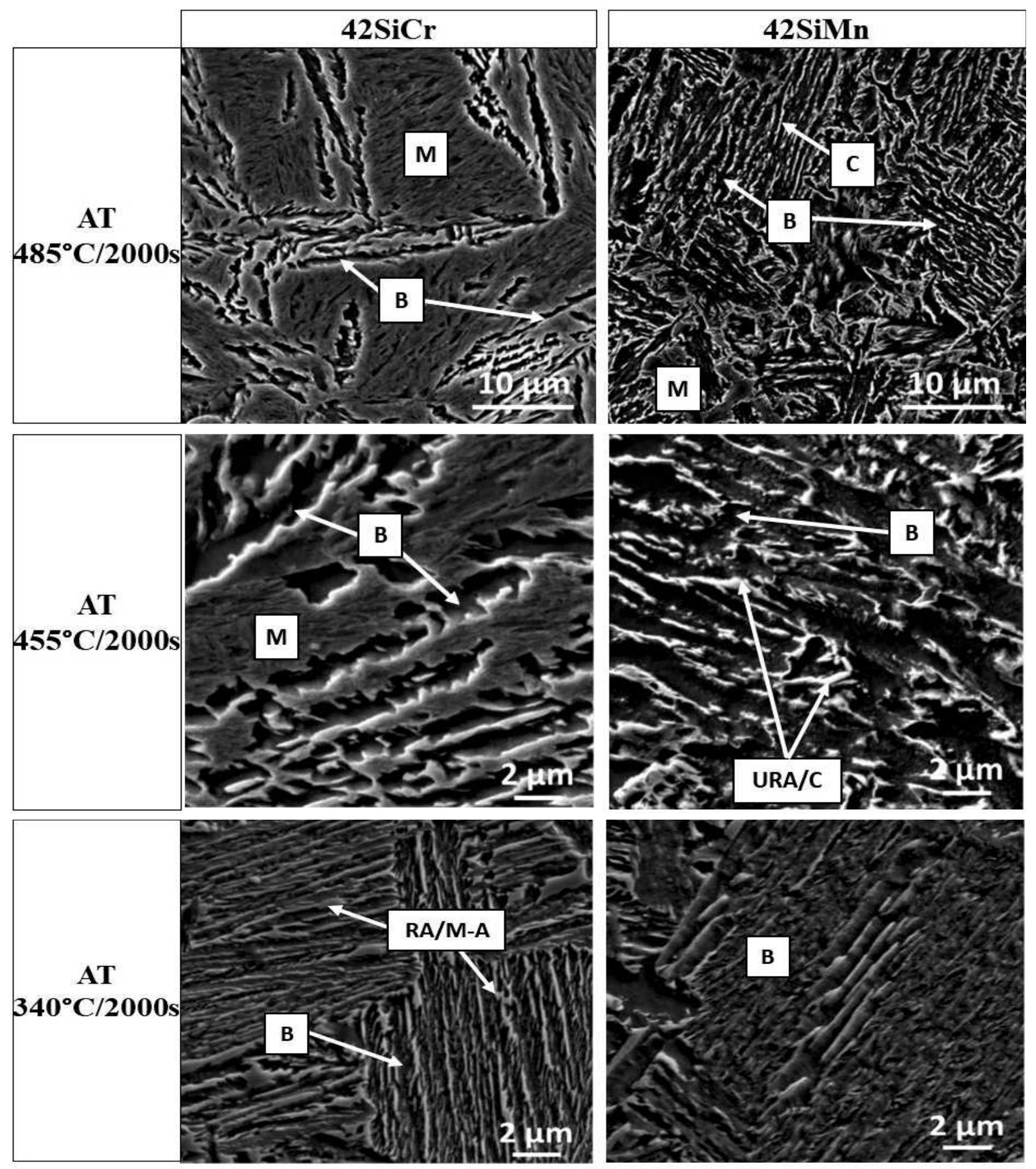

Fig. 4 Microstructures of 42SiCr and 42SiMn steels after isothermal treatment at different temperatures $-B-$ bainite, $C-$ carbides, $\mathrm{R} A$ - retained austenite, $U \mathrm{R} A$ - unstable retained austenite, $M-A-M-A$ constituent

The trend of yield strength (YS) was similar to that of the UTS (Fig. 5, Tab. 2). In 42SiMn, the lowest yield strength YS $=642 \pm 21 \mathrm{MPa}$ was found after the route AT $485^{\circ} \mathrm{C} / 2000 \mathrm{~s}$. The highest YS $=1030 \pm 13 \mathrm{MPa}$ was obtained with AT $340^{\circ} \mathrm{C} / 2000$ s. In $42 \mathrm{SiCr}$, the highest average yield strength YS $=1542 \pm 21 \mathrm{MPa}$ was found after AT $485^{\circ} \mathrm{C} / 2000 \mathrm{~s}$. Analysis of the material suggests that this YS value was, again, a consequence of a majority of virgin martensite in the microstructure. YS decreased with isothermal treatment temperatures. The minimum was reached after AT $420^{\circ} \mathrm{C} / 2000$ s route where the microstructure consisted mainly of bainitic ferrite and probably retained austenite or the M-A constituent. After treatment below $420^{\circ} \mathrm{C}$, the YS values were higher again. It was most likely due to higher strength of the structure consisting of bainite and retained austenite - owing to finer bainitic ferrite needles and chemical and straininduced stabilisation of retained austenite. 
Tab. 2 Yield strength (YS) in austempered specimens of 42SiCr and 42SiMn after isothermal treatment

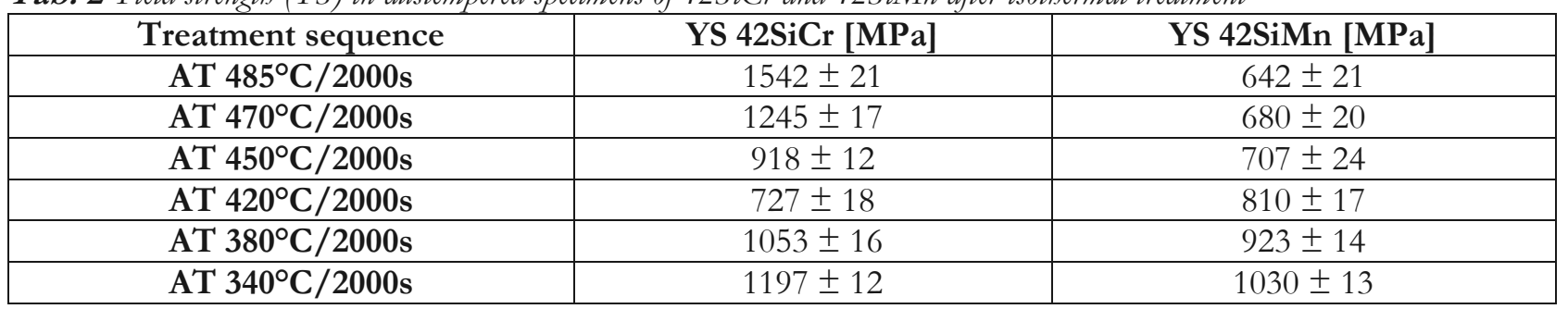

In specimens of $42 \mathrm{SiMn}$, the average total elongation $\mathrm{TE}_{5 \mathrm{~mm}}$ values remained very close after routes with temperatures down to $420^{\circ} \mathrm{C}: 22-24 \%$ (Fig. 6, $\mathrm{Tab} .3)$. In $42 \mathrm{SiCr}$, the presence of virgin martensite in specimens AT 485,470 and $450^{\circ} \mathrm{C} / 2000$ s was the likely cause of the difference in the $\mathrm{TE}_{5 \mathrm{~mm}}$ profile from the trend seen in 42SiMn. Another possible reason of the decrease of total elongation with the treatment temperature in specimens AT 485, 470 and $450^{\circ} \mathrm{C} / 2000$ s was the coarseness of bainitic ferrite. When a predominantly bainitic microstructure was formed, possibly with retained austenite, total elongation was higher. The maximum average $\mathrm{TE}_{5 \mathrm{~mm}}=26 \%$ was found in the AT $380^{\circ} \mathrm{C} / 2000$ s specimen.

Tab. 3 Total elongation $\mathrm{TE}_{5 \mathrm{~mm}}$ in austempered specimens of $42 \mathrm{SiCr}$ and $42 \mathrm{SiMn}$ after isothermal treatment

\begin{tabular}{|c|c|c|}
\hline Treatment route & $\mathrm{TE}_{5 \mathrm{~mm}} 42 \mathrm{SiCr}[\%]$ & $\mathrm{TE}_{5 \mathrm{~mm}} 42 \mathrm{SiMn}[\%]$ \\
\hline AT $485^{\circ} \mathrm{C} / 2000 \mathrm{~s}$ & $10 \pm 1$ & $22 \pm 1$ \\
\hline AT $470^{\circ} \mathrm{C} / 2000 \mathrm{~s}$ & $7 \pm 1$ & $22 \pm 1$ \\
\hline AT $450^{\circ} \mathrm{C} / 2000 \mathrm{~s}$ & $4 \pm 1$ & $23 \pm 1$ \\
\hline AT $420^{\circ} \mathrm{C} / 2000 \mathrm{~s}$ & $18 \pm 1$ & $24 \pm 1$ \\
\hline AT $380^{\circ} \mathrm{C} / 2000 \mathrm{~s}$ & $26 \pm 1$ & $20 \pm 1$ \\
\hline AT $340^{\circ} \mathrm{C} / 2000 \mathrm{~s}$ & $21 \pm 2$ & $14 \pm 1$ \\
\hline
\end{tabular}

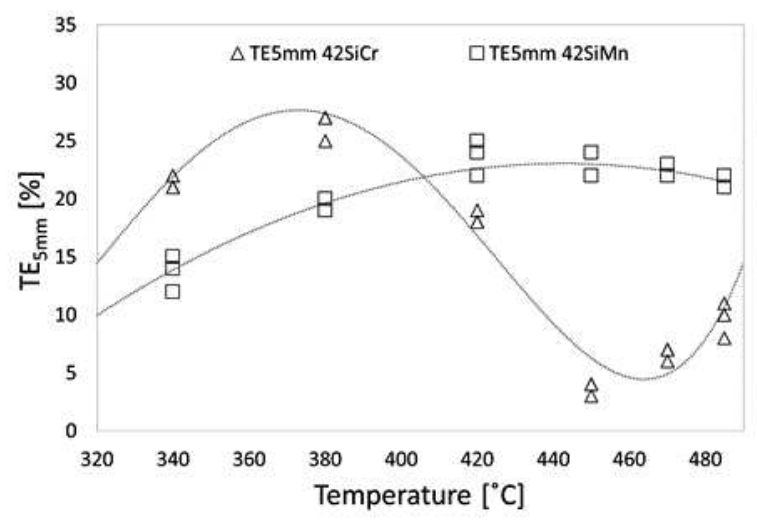

Fig. 6 Total elongation (TE) in austempered specimens of $42 \mathrm{SiCr}$ and $42 \mathrm{SiMn}$ after isothermal treatment

Examination of mechanical properties obtained with routes involving different temperatures revealed that the different chromium addition in 42SiMn $(0.03 \% \mathrm{wt}$.) led to lower UTS in predominantly bainitic structures, the decrease being 200 to $250 \mathrm{MPa}$. It also led to lower YS, by more than $100 \mathrm{MPa}$, and elongation $\mathrm{TE}_{5 \mathrm{~mm}}$ by approximately $6 \%$. Besides the different strengthening behaviour of solid solution, the main reason was the difference in the austenite-bainite transformation. In 42SiMn, the bainitic transformation was complete, and therefore retained austenite decomposed - instead of stabilization. This follows from the TT'T diagrams of both steels, from which it is clear that the 42SiMn steel always fully transformed due to shorter transformation times, and in the case of using lower tempering temperatures, the microstructure was almost fully bainitic. At the same time, carbides precipitated in the material.

\section{Conclusion}

The effect of chromium content on mechanical properties and microstructural evolution in mediumcarbon steels $42 \mathrm{SiCr}$ and $42 \mathrm{SiMn}$ during austempering was explored. The specimens were heat-treated in a thermomechanical simulator: heating to austenitizing temperature of $950^{\circ} \mathrm{C}$, holding for 600 seconds and then quenching to defined temperature: 485, 470, 450, $420,380,340^{\circ} \mathrm{C}$ and holding for 2000 seconds. Isothermal holding was followed by quenching to ambient temperature.

Austempering was proven to lead to attractive and useful combinations of strength and ductility in these steels. In 42SiMn, the highest ultimate strength was UTS $=1313 \pm 18 \mathrm{MPa}$, with yield strength YS $=1030$ $\pm 13 \mathrm{MPa}$ and total elongation TE5mm $14 \pm 1 \%$ in the specimens which were held at $340^{\circ} \mathrm{C}$. Their microstructures consisted of bainitic ferrite and possibly unstable retained austenite which showed signs of decomposition accompanied by precipitation of carbides. Higher temperatures of isothermal treatment led to lower ultimate and yield strength and higher elongation. The highest strength UTS $=907 \pm 16$ $\mathrm{MPa}, \mathrm{YS}=642 \pm 21 \mathrm{MPa}$ and total elongation TE $5 \mathrm{~mm}=22 \%$ were found in specimens which were 
isothermally treated at $485^{\circ} \mathrm{C}$. Their structure comprised predominantly bainitic ferrite and carbide precipitates and possibly unstable retained austenite.

Specimens of $42 \mathrm{SiCr}$ underwent incomplete bainitic transformation and the amount of virgin martensite substantially dictated their mechanical properties. As a consequence, the highest UTS $=2073 \pm 36 \mathrm{MPa}$, YS $=1542 \pm 21 \mathrm{MPa}$ and total elongation of TE $5 \mathrm{~mm}=$ $10 \%$ was found in specimens which had been isothermally held at $485^{\circ} \mathrm{C}$. Lower isothermal holding temperatures led to less martensite in the microstructure. This was the cause of the decreasing UTS, YS and TE5 $\mathrm{mm}$ with lower isothermal treatment temperatures (as opposed to 42SiMn steel). Predominantly bainitic specimens which were isothermally-treated at 380 and $340^{\circ} \mathrm{C}$ had ultimate strength of UTS $=1363$ $\pm 18 \mathrm{MPa}$ and UTS $=1542 \pm 14 \mathrm{MPa}$, respectively, yield strengths YS $=1053 \pm 16 \mathrm{MPa}$ and $\mathrm{YS}=1197$ $\pm 12 \mathrm{MPa}$, respectively, and total elongation of TE $5 \mathrm{~mm}=26 \pm 1$ and $21 \pm 2 \%$, respectively.

The addition of chromium in $42 \mathrm{SiCr}$ secured better mechanical properties than in 42SiMn. The likely mechanisms were solid solution strengthening and stabilization of retained austenite without carbide precipitation. In $42 \mathrm{SiCr}$, the microstructure was predominantly bainitic and the bainitic transformation was incomplete; its mechanical properties were approximately $10 \%$ higher than in $42 \mathrm{SiMn}$, in which the transformation was complete. he mechanical properties and the resulting microstructures of both steels were closely related to the TTT diagrams, which were calculated for this experiment in the software JMatPro. $42 \mathrm{SiCr}$ steel has not undergone a full transformation, its diagram is shifted to significantly longer transformation times compared to the second steel, 42SiMn. On the other hand, 42SiMn steel underwent a full transformation in all cases, and with a lower tempering temperature, the almost fully bainitic structure was obtained in this way.

\section{Acknowledgement}

The present contribution has been prepared with the support of the student grant competition of University of West Bohemia in Pilsen, SGS-2018045 Design of heat and thermo-mechanical treatment of high strength steels of the third generation. The project is subsidised from specific resources of the state budget for research and development.

\section{References}

[1] VOREL, I., JENÍČEK, Š., JIRKOVÁ, H. (2018). Nekonvenční zpracování nové generace vysokopevnostních výkovků. In: MM Primmyslové spektrum, Vol. 2018, No. 1, pp. 42. ISSN: 1212-2572

[2] PEKOVIĆ, M., VOREL, I., KÁŇA, J., OPATOVÁ, K. (2017). Evolution of microstructure and mechanical properties in steels during isothermal holding in the region of bainitic transformation temperature in dependence on silicon content. In: Manufacturing Technology, Vol. 17, No. 4/2017, pp. 549-555. ISSN: 1213-2489

[3] PEKOVIĆ, M., JENÍČEK, Š., RUBEŠOVÁ, K., VOREL, I., JIRKOVÁ, H. (2018). Welding of 42SiCr High-Strength Steel. In: Manufacturing Technology, Vol. 18, No. 1, pp. 84-89. ISSN: 1213-2489

[4] VOREL, I., JENÍČEK, Š., KÁŇA, J., IBRAHIM, K., KOTĚŠOVEC, V., MAŠEK, B. (2017). Effect of silicon content on microstructure of low-alloy Q\&P-Processed steel. In: IOP Conference Series-Materials Science and Engineering, pp. 1-6. ISSN: 1757-8981

[5] JENÍČEK, Š., VOREL, I., KÁŇA, J., IBRAHIM, K., KOTĚŠOVEC, V. (2017). Effect of silicon on stability of austenite during isothermal annealing of low-alloy steel with medium carbon content in the transition region between pearlitic and bainitic transformation. In: IOP Conference Series-Materials Science and Engineering, pp. 1-6. ISSN: 1757-8981

[6] PEKOVIĆ, M., JENÍČEK, Š., VOREL, I., KÁŇA, J., OPATOVÁ, K. (2017). Vliv kř̀emíku na vývoj mikrostruktury ocelí při izotermické prodlevě v oblasti teplot bainitické transformace. Strojirenská technologie, Vol. 22, No. 1, pp. 53-57. ISSN: 1211-4162

[7] KOTĚŠOVEC, V., VOREL, I., JENÍČEK, Š., KÁŇA, J., IBRAHIM, K. (2017). Impact of quenching temperature and isothermal holding time during austempering on bainite content in high-silicon steel. In: IOP Conference Series-Materials Science and Engineering, pp. 1-5, ISSN: 17578981

[8] KÁŇA, J., VOREL, I., RONEŠOVÁ, A. (2016). Simulator of Thermomechanical Treatment of Metals. In: $D A A A M$ International Vienna 2015, pp. 0513-0518. ISBN: 978-3902734-07-5, ISSN: 1726-9679 